Artikel Penelitian

\title{
Aktivitas Antioksidan Kombinasi Madu Monoflora dengan Ekstrak Daun Namnam (Cynometra cauliflora L.)
}

\author{
La Ode Sumarlin*, Melina Hadera, Sri Yadial Chalid, Dede Sukandar
}

Program Studi Kimia, Fakultas Sains dan Teknologi, UIN Syarif Hidayatullah Jakarta, Tangerang Selatan, Indonesia, 1542

\section{INFO ARTIKEL}

\section{Riwayat Artikel}

Direvisi 8 Nomber 2018

Diterima 15 November 2018

Tersedia online 21 November 2018

\footnotetext{
*Email penulis korespondensi: sumarlin@uinjkt.ac.id
}

\section{ABSTRAK}

Honey and namnam leaves (Cynometra cauliflora L.) have been shown to have antioxidant activity. Combination of both materials potent to be used as functional food. In this study, antioxidant activity of samples was measured by the DPPH method $(1,1$ diphenyl-2-picrylhydrazyl) $\left(\mathrm{IC}_{50}\right)$ while total phenolic, total flavonoids, and vitamin $\mathrm{C}$ were determinated by UV-Vis spectrophotometry. Honey samples used were commercial packaging rambutan honey (MR), commercial packaging rubber honey (MK), and commercial unpackaging rambutan honey (MR2). The combination ratio of honey and namnam leaves extract was 1:1, 1:2 and 2:1 (b/b). The highest value of total phenolic, total flavonoids, vitamin $\mathrm{C}$ and antioxidant activity in namnam leaves extract $(\mathrm{N})$ was 267.690 $\mathrm{mg} \mathrm{GAE} / \mathrm{g}, 12.284 \mathrm{mg} \mathrm{QE} / \mathrm{g}, 203.500 \mathrm{mg} \mathrm{AA} / \mathrm{g}$ and $\mathrm{IC}_{50} 0.004 \mathrm{mg} / \mathrm{mL}$, respectively. The highest value of total phenolic was $0.588 \mathrm{mg} \mathrm{GAE} / \mathrm{g}$ in MR2, while the highest value of total flavonoids and antioxidant activity $\left(\mathrm{IC}_{50}\right)$ were $0.027 \mathrm{mg} \mathrm{QE} / \mathrm{g}$ and $21.576 \mathrm{mg} / \mathrm{mL}$ in in $M R$, respectively. Combination MR and MR2 with namnam leaves extract (MR-N and MR2-N) with ratio $1: 2$ gave the highest antioxidant activity with $I C_{50}$ value $0.005 \pm 0.000$ $\mathrm{mg} / \mathrm{mL}$ in both samples. The highest value of total phenolic, total flavonoid, and vitamin $\mathrm{C}$ in MR-N and MR2-N was $266.027 \mathrm{mg} \mathrm{GAE} / \mathrm{g}, 9.790 \mathrm{mg} \mathrm{QE} / \mathrm{g}$, and $100.33 \mathrm{mg} \mathrm{AA} / \mathrm{g}$, respectively. Therefore, the combination is potential as a functional food.

Keywords: Antioxidant, Cynometra cauliflora L., Honey, Total Phenolic, Vitamin C

Madu dan daun namnam (Cynometra cauliflora) telah terbukti memiliki aktivitas antioksidan. Kombinasi kedua bahan ini akan sangat potensial digunakan sebagai pangan fungsional. Pada penelitian ini, antioksidan diukur dengan metode DPPH (1,1-difenil-2pikrilhidrazil) $\left(\mathrm{IC}_{50}\right)$, sedangkan total fenolik, total flavonoid, vitamin $\mathrm{C}$ menggunakan spektrofotometer UV-Vis. Sampel madu yang digunakan adalah madu rambutan kemasan komersial (MR), madu karet kemasan komersial (MK), dan madu rambutan tanpa kemasan komersial (MR2). Perbandingan kombinasi madu dan ekstrak daun namnam masing-masing 1:1, 1:2 dan 2:1 (b/b). Hasil analisis menunjukkan bahwa total fenolik, total flavonoid, vitamin $\mathrm{C}$ dan aktivitas antioksidan tertinggi terdapat pada ekstrak daun namnam (N) masing-masing sebesar 267,690 mg GAE/g, 12,284 mg QE/g, 203,500 mg $\mathrm{AA} / \mathrm{g}$ dan $\mathrm{IC}_{50} 0,004 \mathrm{mg} / \mathrm{mL}$. Kandungan total fenolik tertinggi pada sampel madu adalah MR2 sebesar $0,588 \mathrm{mg} \mathrm{GAE} / \mathrm{g}$, sedangkan total flavonoid dan aktivitas antioksidan tertinggi pada MR yaitu $0,027 \mathrm{mg}$ QE/g dan $\mathrm{IC}_{50} 21,576 \mathrm{mg} / \mathrm{mL}$. Sampel MR dan MR2 kombinasi dengan ekstrak daun namnam (MR-N dan MR2-N) dengan perbandingan 1:2 memberikan aktivitas antioksidan tertinggi dengan nilai $\mathrm{IC}_{50}$ sebesar $0,005 \pm 0,000 \mathrm{mg} / \mathrm{mL}$. Total fenolik, total flavonoid, dan vitamin C tertinggi pada kombinasi MR-N dan MR2-N masing-masing sebesar 266,027 mg GAE/g, 9,790 mg QE/g, dan 100,33 mg AA/g. Oleh karena itu, kombinasi tersebut potensial sebagai pangan fungsional. 


\section{Pendahuluan}

Dampak dari kemajuan teknologi dan informasi menuntut pola hidup instan sehingga menyebabkan perubahan pola konsumsi masyarakat Indonesia terutama masyarakat perkotaan. Konsumsi makanan cepat saji merupakan junk food yang mengandung nilai nutrisi, serat, vitamin $\mathrm{C}$, vitamin $\mathrm{A}$, kalsium, folat yang rendah dan tinggi kalori, lemak tidak jenuh yang berdampak buruk bagi kesehatan [1]. Tingginya kandungan lemak tidak jenuh dapat memicu terbentuknya radikal bebas. Radikal bebas tersebut dapat merusak lipid, protein, asam nukleat dan menginisiasi timbulnya penyakit degeneratif $[2,3]$. Antioksidan merupakan komponen yang memiliki kemampuan untuk menangkal serangan radikal bebas. Salah satu sumber antioksidan alami yang dapat dimanfaatkan adalah madu dan daun namnam (Cynometra cauliflora L.).

Madu dikenal memiliki banyak manfaat karena dapat digunakan untuk berbagai kepentingan. Hasil penelitian sebelumnya telah menunjukkan bahwa beberapa sampel madu yang diambil dari wilayah lokal Indonesia memiliki fungsi sebagai antioksidan. Madu yang memiliki antioksidan tersebut antara lain madu trigona [4], madu klengkeng dan rambutan [5] serta madu Papua [6]. Kemampuan antioksidan madu juga ditunjukkan pada madu Slovenia [7], madu Portugis [8] dan madu Brazil [9]. Menurut Alvarez-Suarez dkk.[10], aktivitas antioksidan madu sangat bervariasi tergantung pada sumber bunga.

Bahan alam lain yang juga potensial sebagai sumber antioksidan adalah daun namnam. Pemilihan daun namnam pada penelitian ini karena namnam merupakan tanaman obat yang mengandung antioksidan tinggi terutama pada bagian daun [11]. Analisis terhadap aktivitas antioksidan menunjukkan bahwa ekstrak metanol daun namnam memberikan aktivitas tertinggi $\left(\mathrm{IC}_{50} 0,0048 \pm 0,000 \mathrm{mg} / \mathrm{mL}\right)$ [4]. Ado dkk. [12] menyebutkan 18 komponen yang teridentifkasi sebagai fraksi bioaktif pada tanaman ini yaitu prosianidin trimer, prosianidin tetramer, prosianidin heksamer, taksifolin pentosida, katekin, viteksin, isoviteksin, kaempferol heksosida, kuersetin pentosida, kuersetin heksosida, apigenin-6-C-glukosida-8C-glukosida, kaempferol-koumaril heksosida dan isorhamnetin heksosida.

Penelitian mengenai kombinasi madu sebagai antioksidan telah banyak dilakukan, diantaranya kombinasi madu seperti kombinasi madu dan Nigella sativa [13], kombinasi madu dan Garcinia Kola [14], kombinasi madu alam dan benih Peganum harmala [15], serta kombinasi madu dan tepung kentang [16]. Kombinasi-kombinasi tersebut menghasilkan efek sinergis sehingga meningkatkan aktivitas antioksidannya. Sumarlin dkk. [4] menyatakan bahwa kemampuan antioksidan kombinasi EMDN (Ekstrak Metanol Daun Namnam) dan Madu Trigona (IC $\mathrm{C}_{50} \quad 0,0085 \pm 0,000 \mathrm{mg} / \mathrm{mL}$ ) lebih tinggi dibandingkan komposisi tunggal Madu Trigona ( $\left(\mathrm{C}_{50} 3,736 \pm 0,112 \mathrm{mg} / \mathrm{mL}\right)$. Oleh karena itu, kombinasi dari madu monoflora dengan ekstrak daun namnam berpotensi untuk dikembangkan sebagai pangan fungsional.

\section{Bahan dan Metode}

\subsection{Bahan}

Sampel yang digunakan adalah madu lokal kemasan komersial madu rambutan (MR), madu perternakan lebah madu rambutan tanpa kemasan komersial (MR2), dan madu karet (MK) dan daun namnam (Cynometra cauliflora L.) dengan pelarut metanol pro analysis (Merck). Uji fitokimia menggunakan beberapa bahan yaitu $\mathrm{H}_{2} \mathrm{SO}_{4}$ pekat (Merck), pereaksi Dragendorff, pereaksi Bourchardat, serbuk magnesium (Merck), asam klorida pekat (Merck), besi (III) klorida (Merck), $\mathrm{NaOH} \mathrm{10 \%} \mathrm{(Merck)} \mathrm{dan} \mathrm{kloroform-amonia.} \mathrm{Bahan} \mathrm{lain} \mathrm{yang} \mathrm{digunakan} \mathrm{yaitu} \mathrm{reagen} \mathrm{Folin-Ciocalteu} \mathrm{(Merck),}$ natrium karbonat, akuades, asam galat (Sigma-Aldrich), alumunium klorida (Merck), kuersetin (Sigma-Aldrich), asam metafosforik (Merck), asam askorbat (Merck), 2,6-dichlorophenolindophenol (DCPIP) (Merck), 2,2-difenil-1-pikrilhidrazil (Sigma-Aldrich), dan kertas Whatman.

\subsection{Preparasi Sampel dan Ekstraksi Daun Namnam}

Daun namnam dikeringkan selama 3 hari di bawah sinar matahari langsung kemudian diserbukkan dengan blender selama 3 menit. Seratus gram serbuk halus daun namnam dimaserasi menggunakan metanol sebanyak $500 \mathrm{~mL}$ selama 24 jam. Campuran disaring dengan kertas saring Whatman no.1 sehingga diperoleh filtrat pertama. Residu daun namnam dimaserasi kembali dengan metanol selama 9 jam sehingga diperoleh filtrat kedua. Proses ini dilakukan sebanyak 5 kali ekstraksi. Filtrat yang diperoleh dikumpulkan kemudian dipekatkan menggunakan rotary evaporator hingga diperoleh ekstrak pekat daun namnam (N).

Sampel madu yang digunakan adalah madu dengan kemasan komersial yang terdiri dari madu rambutan (MR) yang diperoleh dari Pondok Lebah Bekasi dan madu karet (MK) dari Cibubur, madu rambutan tanpa kemasan komersial (MR2) dari perternakan lebah madu Bogor. Madu yang digunakan tidak dilakukan proses ekstraksi seperti pada daun namnam. Kombinasi madu dengan ekstrak daun namnam (N) diberi kode MR-N untuk kombinasi madu rambutan dengan ekstrak daun namnam, MK-N untuk kombinasi madu karet dengan ekstrak daun namnam, dan MR2-N untuk kombinasi madu rambutan tanpa kemasan komersial dengan ekstrak daun namnam. Masing-masing kombinasi antara madu dengan 
ekstrak daun namnam dibuat perbandingan 1:1; 2:1 dan 1:2 (b/b). Pada penelitian ini digunakan 13 jumlah sampel yang terdiri dari 4 sampel tunggal (N, MR, MR2, dan MK) dan 9 sampel kombinasi dengan berbagai perbandingan.

\subsection{Uji Fitokimia}

Prosedur pengujian fitokimia didasarkan pada Harborne [17].

\subsubsection{Identifikasi Golongan Senyawa Alkaloid}

Sampel sebanyak $0,5 \mathrm{~g}$ ditambah $10 \mathrm{~mL}$ kloroform-amonia dan diaduk dan disaring. Filtrat ditambahkan 3-5 tetes $\mathrm{H}_{2} \mathrm{SO}_{4} 2 \mathrm{M}$, kemudian dikocok hingga terbentuk dua lapisan. Lapisan asam (terdapat pada bagian atas) dipipet dalam dua tabung reaksi lain, lalu ditambahkan beberapa tetes pereaksi Dragendorff pada tabung A dan pereaksi Bourchardat pada tabung B. Adanya alkaloid ditunjukkan dengan terbentuknya endapan jingga sampai merah coklat.

\subsubsection{Identifikasi Golongan Senyawa Tanin/Fenolik}

Sampel sebanyak $0,5 \mathrm{~g}$ ditambah 10 tetes $\mathrm{FeCl}_{3} 1 \%$. Sampel positif mengandung tanin/fenol apabila menghasilkan warna hijau, merah, ungu, biru atau hitam pekat.

\subsubsection{Identifikasi Golongan Senyawa Flavonoid}

Sampel sebanyak $0,5 \mathrm{~g}$ ditambah dengan $10 \mathrm{~mL}$ air panas, dan didihkan selama 5 menit, kemudian disaring. Filtrat sebanyak $5 \mathrm{~mL}$ ditambahkan $\mathrm{HCl}$ pekat dan $0,05 \mathrm{mg}$ serbuk $\mathrm{Mg}$, kemudian dikocok kuat-kuat. Uji positif ditunjukkan dengan terbentuknya warna merah, kuning, atau jingga.

\subsubsection{Identifikasi Golongan Senyawa Triterpenoid dan Steroid}

Sampel sebanyak $0,5 \mathrm{~g}$ ditambah dengan $20 \mathrm{~mL}$ n-heksana dan didiamkan selama 2 jam. Kemudian, sampel disaring dan ditambahkan 2 tetes $\mathrm{H}_{2} \mathrm{SO}_{4}$ pekat. Steroid memberikan warna biru atau hijau, sedangkan untuk triterpenoid memberikan warna merah atau ungu.

\subsubsection{Identifikasi Golongan Senyawa Saponin}

Sampel sebanyak $0,5 \mathrm{~g}$ ditambah air panas sebanyak $5 \mathrm{~mL}$ dalam tabung reaksi dan dikocok. Sampel dinyatakan positif mengandung saponin apabila terbentuk busa dengan ketinggian $1-3 \mathrm{~cm}$ yang bertahan selama 15 menit.

\subsubsection{Identifikasi Golongan Senyawa Kuinon}

Sampel sebanyak $0,5 \mathrm{~g}$ ditambah etanol $95 \%$ sebanyak $2 \mathrm{~mL}$, lalu ditambahkan $\mathrm{NaOH} 10 \%$. Jika terjadi pembentukan warna kuning, jingga, coklat, atau merah menunjukkan adanya fenol hidrokuinon.

\subsection{Uji Kadar Total Fenolik, Flavonoid dan Vitamin C}

Masing-masing sampel ditimbang sebanyak $100 \mathrm{mg}$ dan dilarutkan dalam $10 \mathrm{~mL}$ akuades. Selanjutnya, campuran diambil sebanyak $0,5 \mathrm{~mL}$ dan ditambahkan dengan 0,3 mL Folin Ciocalteu, $2 \mathrm{~mL} \mathrm{Na} \mathrm{CO}_{3}$ 15\% dan 2,2 $\mathrm{mL}$ akuades. Larutan dihomogenkan dan diinkubasi selama 2 jam dalam ruang gelap lalu diukur serapannya menggunakan spektrofotometer UV-Vis (Perkin Elmer Precisely) pada panjang gelombang $750 \mathrm{~nm}$ dengan akuades sebagai blanko [9]. Asam galat (0-100 ppm) digunakan untuk menentukan kurva kalibrasi. Pengukuran dilakukan sebanyak 3 kali dan kandungan fenolik dinyatakan sebagai jumlah mg Gallic Acid Equivalent (GAE)/g sampel.

Masing-masing sampel sebanyak $0,2 \mathrm{~g}$ dilarutkan dalam $10 \mathrm{~mL}$ metanol pada tabung reaksi. Setelah itu, $5 \mathrm{~mL}$ campuran ditambahkan pereaksi $\mathrm{AlCl}_{3} 2 \%$ (b/v) sebanyak $5 \mathrm{~mL}$. Larutan dihomogenkan dan diinkubasi selama 10 menit lalu diukur serapannya menggunakan spektrofotometer UV-Vis pada panjang gelombang $415 \mathrm{~nm}$ dengan metanol sebagai blanko [18]. Kuersetin (0-50 ppm) digunakan untuk menentukan kurva kalibrasi. Pengukuran dilakukan sebanyak 3 kali dan kandungan flavonoid dianggap sebagai jumlah mg Quercetin Equivalent (QE)/g sampel.

Masing-masing sampel sebanyak $0,1 \mathrm{~g}$ dilarutkan dalam $10 \mathrm{~mL}$ asam metafosforik $1 \%$ lalu diinkubasi selama 45 menit. Larutan disaring menggunakan Whatman No. 41, kemudian $1 \mathrm{~mL}$ filtrat yang diperoleh ditambahkan $9 \mathrm{~mL}$ DCPIP. Larutan diinkubasi selama 30 menit pada suhu ruang lalu diukur serapannya menggunakan spektrofotometer UV-Vis pada panjang gelombang $519 \mathrm{~nm}$ [8]. Asam askorbat (0-200 ppm) digunakan untuk menentukan kurva kalibrasi. Pengukuran dilakukan sebanyak 3 kali dan kandungan vitamin $C$ dinyatakan sebagai jumlah $\mathrm{mg}$ Ascorbic Acid (AA)/g sampel. 


\subsection{Uji Aktivitas Antioksidan}

Masing-masing madu monoflora dibuat berbagai konsentrasi yaitu 1000, 2000, 4000, 8000, 16000, 32000, 64000 dan $128000 \mathrm{mg} / \mathrm{L}$. Adapun ekstrak daun namnam (N) dan kombinasi madu dengan ekstrak daun namnam (MR, MR2, MK) dibuat deret konsentrasi 0,$5 ; 1 ; 2 ; 4$ dan 8 mg/L. Selanjutnya, masing-masing variasi konsentrasi diambil sebanyak 2 $\mathrm{mL}$ dan ditambahkan dengan $2 \mathrm{~mL}$ DPPH 0,002\%. Larutan kemudian dihomogenkan menggunakan vortex dan diinkubasi selama 30 menit dalam ruang gelap. Selanjutnya, dilakukan pengukuran terhadap serapan larutan menggunakan spektrofotometer UV-Vis pada panjang gelombang $517 \mathrm{~nm}$. Pengukuran dilakukan sebanyak 3 kali. Asam askorbat (0,125-4 ppm) digunakan sebagai kontrol positif.

Aktivitas antioksidan sampel ditentukan persen inhibisi (\% inhibisi) ditentukan berdasarkan Persamaan 1. Selain itu, ditentukan pula aktivitas antioksidan berdasarkan nilai $\mathrm{IC}_{50}$. [12].

$$
\% \text { Inhibisi }=\frac{\text { (Absorbansi kontrol }- \text { Absorbansi sampel) }}{\text { Absorbansi kontrol }} \times 100 \%
$$

\section{Hasil dan Pembahasan}

\subsection{Hasil Uji Fitokimia}

Tanaman mempunyai kemampuan untuk memproduksi berbagai macam metabolit sekunder seperti saponin, tanin, fenol, triterpenoid dan fitosterol [19]. Hal ini dapat dilihat bahwa ekstrak daun namnam (N) menunjukkan hasil positif pada uji kualitatif (Tabel 1). Hasil ini sesuai dengan penelitian Aziz \& Iqbal [11] yang menyatakan bahwa ekstrak daun namnam (N) mengandung senyawa metabolit sekunder seperti tanin, saponin, flavonoid, terpenoid dan glikosida. Hasil yang sama juga ditunjukkan pada kombinasi madu dengan ekstrak daun namnam. Hal ini mengindikasikan bahwa golongan senyawa saponin, fenolik, flavonoid, kuinon, terpenoid dan steroid berasal dari ekstrak daun namnam (N). Pada uji golongan senyawa kuinon dan saponin, kedua bahan sampel dalam bentuk tunggal menghasilkan kandungan positif. Hal ini menandakan adanya kontribusi dari madu dan ekstrak daun namnam $(\mathrm{N})$ sehingga sampel kombinasi menghasilkan uji positif pada uji golongan.

Tabel 1. Hasil Pengujian Fitokimia

\begin{tabular}{cccccc}
\hline Golongan Senyawa & MR & MR2 & MK & N & $\begin{array}{c}\text { Kombinasi Madu-Ekstrak Daun } \\
\text { Namnam }\end{array}$ \\
\hline Alkaloid & - & - & - & - & - \\
Fenolik & - & - & - & + & + \\
Flavonoid & - & - & - & + & + \\
Saponin & + & + & + & + & + \\
Kuinon & - & + & - & + & + \\
Terpenoid dan Steroid & - & - & - & + & + \\
\hline
\end{tabular}

MR = Madu Rambutan Kemasan Komersial; MR2 = Madu Rambutan Tanpa Kemasan Komersial; MK = Madu Karet; N = Ekstrak Daun Namnam

Tanda " + "menunjukkan terdeteksi metabolit sekudener, sedangkan tanda " - menunjukkan tidak terdeteksi metabolit sekunder.

Madu banyak menunjukkan hasil negatif pada uji kualitatif golongan senyawa. Hal ini dapat disebabkan karena kandungan senyawa metabolit sekunder rendah. Hasil kuantitatif fenolik dan flavonoid (Tabel 2) menunjukkan bahwa madu mengandung total fenolik yang rendah $(0,298-0,588 \mathrm{mg}$ GAE/g) sehingga tidak terdeteksi pada uji kualitatif . Selain itu, nektar bunga dapat mempengaruhi kandungan nutrisi madu. Jenis bunga yang digunakan sebagai sumber nektar oleh lebah dapat mempengaruhi komposisi dari madu yang dihasilkan [20, 21].

Senyawa metabolit sekunder mempunyai beberapa aktivitas biologi. Fenolik dilaporkan sebagai agen antioksidan [22]. Flavonoid mempunyai aktivitas antiproliferatif terhadap sel kanker [23], melindungi membran lipid dari oksidasi [24]. Golongan senyawa saponin memiliki potensi sebagai antihiperglikemia, antidiabetes dan hipokolesterolemik [25]. Golongan alkaloid mempunyai fungsi sebagai anti analgesik, meningkatkan dan menurunkan tekanan darah [26]. Sementara itu, golongan senyawa terpenoid dapat berperan penting dalam menyembuhkan bekas luka [27].

\subsection{Komposisi Senyawa Antioksidan}

Analisis komponen kimia antioksidan meliputi pengujian kandungan total fenolik, total flavonoid dan vitamin C terhadap madu, ekstrak daun namnam dan kombinasi madu dengan ekstrak daun namnam (Tabel 2). Pengujian ini dilakukan untuk melihat pengaruh komponen penyusun sampel uji. 
Tabel 2. Kandungan Total Fenolik, Total Flavonoid dan Vitamin C

\begin{tabular}{|c|c|c|c|c|}
\hline Sampel & Status & $\begin{array}{l}\text { Total Fenolik } \\
\text { (mg GAE/g)* }\end{array}$ & $\begin{array}{l}\text { Total Flavonoid } \\
\text { (mg QE/g)* }\end{array}$ & $\begin{array}{c}\text { Vitamin C } \\
(\text { mg AA/g)* }\end{array}$ \\
\hline$\overline{\mathrm{N}}$ & Tunggal & $267,690 \pm 7,271$ & $12,284 \pm 0,168$ & $203,500 \pm 15,000$ \\
\hline MK & Tunggal & $0,298 \pm 0,076$ & $0,012 \pm 0,003$ & $37,197 \pm 3,472$ \\
\hline MR2 & Tunggal & $0,588 \pm 0,083$ & $0,020 \pm 0,004$ & $30,917 \pm 2,887$ \\
\hline MR & Tunggal & $0,508 \pm 0,015$ & $0,027 \pm 0,005$ & $15,917 \pm 3,819$ \\
\hline MK-N (1:1) & Kombinasi & $133,489^{a} \pm 4,990$ & $5,9^{\circ} \pm 0,024$ & $44,625^{b} \pm 2,165$ \\
\hline MR2-N (1:1) & Kombinasi & $160,285^{b, c} \pm 6,253$ & $6,411^{d} \pm 0,087$ & $28,375^{\mathrm{b}, \mathrm{a}} \pm 1,250$ \\
\hline MR-N (1:1) & Kombinasi & $145,014^{a, b} \pm 0,083$ & $6,565^{d} \pm 0,161$ & $26,708^{a} \pm 2,602$ \\
\hline MK-N (1:2) & Kombinasi & $165,759 c \pm 6,545$ & $9,019 \mathrm{e} \pm 0,143$ & $223,667^{f} \pm 5,774$ \\
\hline MR2-N (1:2) & Kombinasi & $266,027 \mathrm{e} \pm 3,992$ & $9,069 \mathrm{e} \pm 0,155$ & $100,333^{e} \pm 11,547$ \\
\hline MR-N (1:2) & Kombinasi & $227,768^{d} \pm 10,797$ & $9,790^{f} \pm 0,069$ & $70,917 c \pm 7,638$ \\
\hline MK-N (2:1) & Kombinasi & $140,087^{a} \pm 13,194$ & $4,852^{a} \pm 0,033$ & $96,750^{\mathrm{d}, \mathrm{e}} \pm 2,500$ \\
\hline MR2-N (2:1) & Kombinasi & $143,837^{a, b} \pm 12,976$ & $4,870 \mathrm{a} \pm 0,022$ & $87,583^{\mathrm{d}} \pm 1,443$ \\
\hline MR-N (2:1) & Kombinasi & $143,725^{a, b} \pm 10,932$ & $5,070^{c} \pm 0,077$ & $25,917 a \pm 3,819$ \\
\hline
\end{tabular}

*(dinyatakan dalam mean \pm SD). Angka yang diikuti oleh huruf yang sama tidak berbeda nyata pada taraf uji lanjut Duncan $5 \%$ taraf signifikansi 95\% (P<0,05); N (Ekstrak Daun Namnam); MR (Madu Rambutan Kemasan Komersial); MR2 (Madu Rambutan Tanpa Kemasan Komersial); MK (Madu Karet); MR-N (Kombinasi MR dengan Ekstrak Daun Namnam); MR2-N (Kombinasi MR2 dengan Ekstrak Daun Namnam); MK-N (Kombinasi MK dengan Ekstrak Daun Namnam)

Berdasarkan Tabel 2 dapat dilihat bahwa ekstrak daun namnam $(\mathrm{N})$ memiliki kandungan total fenolik, total flavonoid dan vitamin C tertinggi. Hasil penelitian ini berbeda dengan penelitian Ado dkk. [12] dan Aziz \& Iqbal [11] dimana kandungan total fenolik dan total flavonoid daun namnam yaitu sebesar 214,370 mg GAE/g dan 33,63 mg CAE/g, berturut-turut. Komposisi suatu tanaman dipengaruhi oleh faktor geografis, kondisi iklim, sumber tanaman, jenis varietas, kultivar, faktor genetik, perlakuan setelah panen dan kondisi penyimpanan bahan $[28,29,30]$.

Sampel MR, MR2 dan MK memiliki kandungan total fenolik, total flavonoid dan vitamin C yang berbeda. Hal ini juga terjadi pada penelitian Meda dkk. [18] yang menunjukkan bahwa kandungan total fenolik dan flavonoid pada 27 sampel madu dari Burkina Faso, Afrika berkisar antara 32,59-114,75 mg GAE/100 g dan 0,17-8,35 mg QE/100 g. Kishore dkk. [2] menyebutkan bahwa kandungan madu Tualang, Gelam, Indian Forest dan Pineapple memiliki kandungan vitamin C berkisar 14,64-36,09 mg AAE/100 g. Hal ini menunjukkan bahwa daerah asal dari madu mempengaruhi komposisi kimia madu tersebut.

Perbedaan kandungan komposisi dari madu juga dipengaruhi oleh sumber nektar [31] dan faktor eksternal seperti musim, faktor lingkungan, pengolahan dan penyimpanan. Rendahnya kandungan total fenolik, total flavonoid dan vitamin $\mathrm{C}$ dapat disebabkan karena faktor penyimpanan madu dari waktu produksi sampai madu dilakukan analisis. Hal ini sesuai dengan penelitian Saric dkk. [32] yang menyebutkan bahwa kandungan total fenolik dan total flavonoid pada madu akasia yang disimpan selama 6 bulan mengalami penurunan dari 82,26 menjadi 28,94 mg GAE/kg. Meskipun demikian, kandungan total fenolik pada penelitian ini masih lebih besar dibandingkan penelitian Liu dkk. [23] dimana kandungan madu $D$. iongan, $L$. chinensis dan C. maxima mengandung total fenolik berkisar 0,307-0,489 mg GAE/g.

Berdasarkan hasil uji statistik menggunakan One Way ANOVA diperoleh bahwa terdapat perbedaan yang signifikan kandungan total fenolik, total flavonoid dan vitamin $\mathrm{C}$ akibat adanya perlakuan kombinasi. Pada taraf uji lanjut Duncan menunjukkan kombinasi madu dengan ekstrak daun namnam pada perbandingan 1:2 memiliki kandungan total fenolik, total flavonoid dan vitamin C tertinggi. Hal ini disebabkan karena jumlah ekstrak daun namnam lebih dominan dibandingkan madu sehingga komponen yang terkandung dalam sampel lebih besar dibandingkan dengan kombinasi 1:1 dan 2:1. Hal ini dapat dilihat dari hasil uji ekstrak daun namnam memiliki kandungan total fenolik, total flavonoid dan vitamin $\mathrm{C}$ yang lebih besar dibandingkan sampel madu. Semakin banyak jumlah ekstrak daun namnam pada sampel kombinasi maka kadar total fenolik, total flavonoid dan vitamin $\mathrm{C}$ yang terkandung juga semakin tinggi.

Adanya kombinasi madu dengan ekstrak daun namnam dapat mempengaruhi kandungan total senyawa fenolik, total flavonoid dan vitamin C. Hal ini menunjukkan bahwa komposisi suatu bahan alam dapat mempengaruhi kandungan senyawa di dalam bahan tersebut. Pada penelitian ini, kombinasi madu dengan ekstrak daun namnam pada perbandingan 1:2 merupakan kombinasi terbaik. 


\subsection{Aktivitas Antioksidan Sampel}

Berdasarkan Tabel 3 diketahui bahwa nilai $I_{50}$ seluruh sampel berkisar antara 0,004-117,793 mg/mL dengan aktivitas antioksidan tergolong sedang hingga tidak aktif. Aktivitas antioksidan dengan nilai $\mathrm{IC}_{50}$ terendah terdapat pada ekstrak daun namnam $(\mathrm{N})$ sebesar $0,004 \mathrm{mg} / \mathrm{mL}$. Ini menunjukkan bahwa ekstrak daun namnam $(\mathrm{N})$ memiliki aktivitas antioksidan tertinggi pada yang dapat menghambat $50 \%$ radikal DPPH sehingga dapat dikatakan bahwa $\mathrm{N}$ memiliki aktivitas antioksidan sangat kuat. Kuatnya aktivitas antioksidan ekstrak daun namnam (N) dapat disebabkan karena tingginya komponen-komponen antioksidan seperti kandungan total fenolik, total flavonoid dan vitamin $\mathrm{C}$ (Tabel 2). Aktivitas antioksidan $\mathrm{N}$ hasil penelitian ini lebih kuat dibandingkan penelitian Ado dkk. [12] yang menyebutkan nilai $\mathrm{IC}_{50}$ ekstrak metanol daun namnam sebesar $0,048 \mathrm{mg} / \mathrm{mL}$.

Tabel 3. Hasil Uji Aktivitas Antioksidan

\begin{tabular}{lcc}
\hline \multicolumn{1}{c}{ Sampel } & Status & Nilai $\mathbf{C}_{50}(\mathbf{m g} / \mathbf{m L})^{*}$ \\
\hline Vit. C & - & $0,003 \pm 0,000$ \\
MR & Tunggal & $21,576 \pm 0,794$ \\
MR2 & Tunggal & $36,502 \pm 0,824$ \\
MK & Tunggal & $117,793 \pm 1,867$ \\
N & Tunggal & $0,004 \pm 0,000$ \\
MR-N $(1: 1)$ & Kombinasi & $0,008^{\mathrm{c}} \pm 0,000$ \\
MR2-N (1:1) & Kombinasi & $0,009^{\mathrm{c}} \pm 0,000$ \\
MK-N (1:1) & Kombinasi & $0,027^{ \pm} \pm 0,001$ \\
MR-N (1:2) & Kombinasi & $0,005^{\mathrm{a}} \pm 0,000$ \\
MR2-N (1:2) & Kombinasi & $0,005^{\mathrm{a}} \pm 0,000$ \\
MK-N (1:2) & Kombinasi & $0,010^{\mathrm{d}} \pm 0,000$ \\
MR-N $(2: 1)$ & Kombinasi & $0,006^{\mathrm{b}} \pm 0,000$ \\
MR2-N (2:1) & Kombinasi & $0,011^{\mathrm{d}} \pm 0,000$ \\
MK-N (2:1) & Kombinasi & $0,015^{\mathrm{e}} \pm 0,000$ \\
\hline
\end{tabular}

*(dinyatakan dalam mean $\pm \mathrm{SD}$ ). Angka yang diikuti oleh huruf yang sama tidak berbeda nyata pada taraf uji lanjut Duncan 5\% taraf signifikansi 95\% (P<0,05); N (Ekstrak Daun Namnam); MR (Madu Rambutan Kemasan Komersial); MR2 (Madu Rambutan Tanpa Kemasan Komersial); MK (Madu Karet); MR-N (Kombinasi MR dengan Ekstrak Daun Namnam); MR2-N (Kombinasi MR2 dengan Ekstrak Daun Namnam); MK-N (Kombinasi MK dengan Ekstrak Daun Namnam).

Berdasarkan Tabel 3 diketahui nilai IC $\mathrm{C}_{50}$ pada MR, MR2 dan MK sangat besar. Tingginya nilai IC $\mathrm{C}_{50}$ dapat disebabkan oleh sampel madu yang diuji berupa madu utuh tanpa dilakukan proses pemisahan atau fraksinasi senyawa sehingga belum mendapatkan senyawa murni. da Silva dkk. [35] menyebutkan bahwa $\mathrm{IC}_{50}$ aktivitas antioksidan fraksi etil asetat madu lebih kuat $(11,1 \pm 0,1 \mu \mathrm{g} / \mathrm{mL})$ dibandingkan madu utuh $(87,8 \pm 0,9 \mu \mathrm{g} / \mathrm{mL})$. Oleh karena itu, daya inhibisi ketiga madu tersebut terhadap DPPH sangat lemah. Faktor penyimpanan madu dapat menyebabkan penurunan aktivitas antioksidan. Penelitian Saric dkk. [32] menyebutkan bahwa madu akasia yang disimpan selama 6 bulan mengalami peningkatan nilai $\mathrm{IC}_{50}$ dari 44,54 menjadi $53,55 \mathrm{mg} / \mathrm{mL}$.

Sampel MR, MK dan MR2 memiliki nilai $I C_{50}$ yang berbeda. Adanya perbedaan aktivitas antioksidan yang dimiliki masing-masing madu dipengaruhi oleh spesies tanaman, nektar bunga, faktor eksternal dan produk metabolisme asal lebah [31]. Nilai IC $\mathrm{C}_{50}$ MR yang dihasilkan lebih rendah dibandingkan MR2, hal ini menandakan bahwa pengolahan madu tidak mempengaruhi aktivitas antioksidan madu. Penelitian Estenvinho dkk. [34] menyebutkan bahwa $\mathrm{EC}_{50}$ madu Portugal sebesar $27,24 \mathrm{mg} / \mathrm{mL}$ dan $68,17 \mathrm{mg} / \mathrm{mL}$. Hal ini menunjukkan bahwa MR dan MR2 memiliki aktivitas antioksidan yang lebih kuat dibandingkan madu Portugal (Tabel 3).

Pengaruh pencampuran masing-masing madu dengan ekstrak daun namnam dapat diketahui melalui uji antioksidan terhadap kombinasi kedua bahan tersebut. Hasil uji statistik diketahui bahwa terdapat perbedaan secara nyata aktivitas antioksidan pada sampel uji akibat adanya kombinasi. Hasil analisis terhadap pengaruh kombinasi madu dan ekstrak daun namnam terhadap aktivitas antioksidan menunjukkan hasil yang kuat dimana nilai $\mathrm{IC}_{50}$ yang dihasilkan kurang dari 0,05 mg/mL. Sampel MR-N dan MR2-N dengan perbandingan 1:2 merupakan kombinasi yang paling kuat dalam meredam radikal DPPH dengan nilai $\mathrm{IC}_{50}$ sebesar $0,005 \mathrm{mg} / \mathrm{mL}$. Kombinasi yang paling kuat ini terjadi ketika komposisi ekstrak daun namnam lebih besar. Hal ini diduga bahwa aktivitas antioksidan berasal dari ekstrak daun namnam. Hasil tersebut terlihat pada uji tunggal aktivitas antioksidan ekstrak daun namnam lebih tinggi dibandingkan dengan madu. 
Adapun aktivitas antioksidan setelah pencampuran menurut perbandingan 1:1;1:2; 2:1 dari madu dan ekstrak daun namnam, ternyata tidak jauh menurunkan nilai $\mathrm{IC}_{50}$ dari ekstrak daun namnam. Efek pencampuran yang dilakukan hanya mampu meningkatkan aktivitas antioksidan madu, dimana nilai $\mathrm{IC}_{50}$ masing-masing madu tunggal jauh lebih tinggi dibandingkan ekstrak daun namnam. Ketiga formulasi kombinasi menunjukkan sifat antioksidan yang sangat kuat sama seperti aktivitas antioksidan ekstrak daun namnam, dimana nilai $I C_{50}$ yang dihasilkan lebih kecil dari $0,05 \mathrm{mg} / \mathrm{mL}$. Aktivitas antioksidan kombinasi madu dan ekstrak daun namnam masih lebih kecil dibandingakan aktivitas antioksidan ekstrak daun namnam.

Aktivitas antioksidan seluruh sampel juga diuji korelasinya terhadap kadar total fenolik dan vitamin C. Berdasarkan hasil yang diperoleh diketahui bahwa terdapat korelasi yang kuat dan sedang antara kedua senyawa tersebut dengan aktivitas antioksidan. Hal tersebut berdasarkan nilai koefisien korelasi sebesar $-0,664(P<0,01)$ untuk kadar fenolik, sedangkan untuk kadar vitamin $C$ nilai koefisien korelasinya sebesar $-0,280(P<0,01)$. Hal ini menunjukkan bahwa $28 \%$ kapasitas antioksidan pada sampel uji dipengaruhi oleh adanya senyawa vitamin $\mathrm{C}$, sedangkan senyawa fenolik berpengaruh sebesar $66,4 \%$. Kemungkinan besar senyawa-senyawa lain yang juga berkontribusi terhadap aktivitas antioksidan berasal dari senyawa seperti tanin, tokoferol, $\beta$-karoten dan asam-asam organik yang diketahui terkandung dalam sampel madu dan ekstrak daun namnam.

\section{Kesimpulan}

Aktivitas antioksidan ketiga jenis madu relatif rendah jika dibandingkan ekstrak daun namnam. Namun, aktivitas antioksidan hasil kombinasi madu dengan ekstrak daun namnam meningkat dan aktivitas antioksidan tertinggi diperoleh pada kombinasi madu rambutan kemasan komersial (MR) dan bukan kemasan komersial (MR2) dan ekstrak daun namnam. Perbandingan masing-masing madu dan ekstrak namnam tertinggi terdapat pada perbandingan 1:2 dengan nilai $I_{50} \quad 0,005 \pm 0,000 \mathrm{mg} / \mathrm{mL}$. Peningkatan aktivitas antioksidan tersebut sangat dipengaruhi oleh kandungan senyawa fenolik, flavonoid dan vitamin $\mathrm{C}$ yang berkorelasi positif terhadap peningkatan aktivitas antioksidan.

\section{Daftar Pustaka}

[1] R. M. Muliany, "Daftar Kandungan Zat Gizi, Serat dan Indeks Glikemik dalam Penukar Berbagai Hidangan Indonesia dan Makanan Siap Santap Barat untuk Pasien Diabetes Melitus," thesis, Jurusan IImu Gizi, Universitas Dipenogoro, Semarang, 2005.

[2] R. K. Kishore, A. S. Halim, M. S. N. Syazana, \& K. N. S. Sirajudeen, "Tualang Honey has Higher Phenolic Content and Greater Radical Scavenging Activity Compared with Other Honey Sources," Nutrition Research, vol. 31, no.4 pp. 322-325, 2011.

[3] Rohmatussolihat, "Antioksidan, Penyelamat Sel-Sel Tubuh Manusia," BioTrends, vol. 4, no. 1, pp. 5-9, 2009.

[4] L. Sumarlin, A. Suprayogi, M. Rahminiwati, A. Tjachja, \& D. Sukandar, "Bioactivity of Methanol Extract of Namnam Leaves in Combination with Trigona Honey," Jurnal Teknologi dan Industri Pangan, vol. 26, no.2, pp. 144-154, 2015.

[5] L. Sumarlin, A. Tjachja, R. Octavia, \& N. Ernita, "Aktivitas Antioksidan Ekstrak Metanol Madu Cair dan Madu Bubuk Lokal Indonesia," Al-Kimia, vol. 6, no. 1, pp. 10-23, 2018.

[6] L. Sumarlin, A. Muawanah, P. Wardhani, \& Masitoh, "Anticancer and Antioxidant Activity of Honey in the Market Local Indonesia," Jurnal IImu Pertanian Indonesia, vol. 19, no.3, pp. 136-144, 2014.

[7] J. Bertoncelj, U. Doberšek, M. Jamnik, \& T. Golob, "Evaluation of the Phenolic Content, Antioxidant Activity and Colour of Slovenian Honey," Food Chemistry, vol. 105, no. 2, pp.822-828, 2007.

[8] I. C. F. R. Ferreira, E. Aires, J. C. M. Barreira, \& L. M. Estevinho, "Antioxidant Activity of Portuguese Honey Samples: Different Contributions of the Entire Honey and Phenolic Extract," Food Chemistry, vol. 114, no. 4, pp. 1438-1443, 2009.

[9] J. E. Pontis, L. A. M. A. Costa, S. J. R. Silva, \& A. Flach, "Color, Phenolic and Flavonoid Content, and Antioxidant Activity of Honey from Roraima, Brazil," Food Science and Technology, vol. 34, no.1, pp. 69-73, 2014.

[10] J. M. Alvarez-Suarez et al., "Antioxidant and Antimicrobial Capacity of Several Monofloral Cuban Honeys and Their Correlation with Color, Polyphenol and Other Chemical Compounds," Food and Chemical Toxicology, vol. 48, no.8-9, pp. 2490-2499, 2010.

[11] A. F. A. A. Aziz \& M. Iqbal, "Antioxidant Activity and Phytochemical Composition of Cynometra cauliflora," Journal of Experimental and Integrative Medicine, vol. 3, no. 4, pp. 337-341, 2013.

[12] M. A. Ado, F. Abas, I. S. Ismail, H. M. Ghazali, \& K. Shaari, "Chemical Profile and Antiacetylcholinesterase, Antityrosinase, Antioxidant and a-Glucosidase Inhibitory Activity of Cynometra cauliflora L. Leaves," Journal of the Science of Food and Agriculture, vol. 95, no.3, pp. 635-642, 2014. 
[13] A. Meslem, M. Ahmed, N. Djebli, \& S. Aissat, "Antibacterial Activity of Honey Alone and in Combination with Nigella sativa Seeds against Pseudomonas aeruginosa Infection," Asian Pacific Journal of Tropical Disease, vol. 2, no. 1, pp. S248-S430, 2012.

[14] F. I. Akinnibosun \& E. Itedjere, "Evaluation of the Antibacterial Properties and Synergistic Effect of Garcinia kola Heckel (Family: Guttiferae) Seed Extract and Honey on Some Bacteria," African Journal of Microbiology Research, vol. 7, no. 3, pp. 174-180, 2013.

[15] M. Ahmed, B. Khiati, N. Djebli, S. S. Aissat, A. Meslem, \& S. Bacha, "Potent Synergism of the Combination of Natural Honey and Peganum harmala Seeds against Candida albicans ATCC 10231," Open Access Scientific Reports, vol. 2, no. 4, 2013.

[16] M. Ahmed, N. Djebli, S. Aissat, S. Bacha, A. Meslem, \& B. Khiati, "Synergistic Inhibition of Natural Honey and Potato Starch and Their Correlation with Diastase Number and Sugar Content against Klebsiella pneumonia ATCC 27736," Natural Product Chemistry \& Research, vol. 1, no. 1, 2012.

[17] J. R. Harborne, Metode fitokimia Pantunan Cara Metode Menganalisis Tumbuhan, Bandung: ITB Press, 1987.

[18] A. Meda, C. E. Lamien, M. Romito, J. Millogo, \& O. G. Nacoulma, "Determination of the Total Phenolic, Flavonoid and Proline Contents in Burkina Faso Honey, as well as Their Radical Scavenging Activity," Food Chemistry, vol. 91, pp. 571-577, 2005.

[19] D. T. Patil, K. D. Gurav, A. S. Kadam, S. V. Thite, R. B. Thoke, \& B. A. Kore, "Qualitative Analysis of Secondary Metabolites from Some Filicales Members," International Journal of Reseacrch in Pharmacy and Chemistry, vol. 3 , no. 2, pp. 300-302, 2013.

[20] C. Cimpoiu, A. Hosu, V. Miclaus, \& A. Puscas, "Determination of the Floral Origin of Some Romanian Honeys on the Basis of Physical and Biochemical Properties," Spectrochimica Acta Part A: Molecular and Biomolecular Spectroscopy, vol. 100, pp. 149-154, 2013.

[21] J. R. Liu, Y. L. Ye, T. Y. Lin, Y. W. Wang, \& C. C. Peng, "Effect of Floral Sources on the Antioxidant, Antimicrobial, and Anti-inflammatory Activities of Honeys in Taiwan," Food Chemistry, vol. 139, no. 1-4, pp. 938-943, 2013.

[22] A. Wojdylo, J. Oszmianski, \& R. Czemerys, "Antioxidant Activity and Phenolic Compounds in 32 Selected Herbs," Food Chemistry, vol. 105, no. 3, pp. 940-949, 2007.

[23] J. A. Manthey \& N. Guthrie, "Antiproliferative Activities of Citrus Flavonoids against Six Human Cancer Cell Lines," Journal of Agricultural and Food Chemistry, vol. 5, no. 21, pp. 5837-5843, 2002.

[24] C. G. Heijnen, G. R. Haenen, R. M. Oostveen, E. M. Stalpers, \& A. Bast, "Protection of Flavonoids against Lipid Peroxidation: The Structure Activity Relationship Revisited," Free Radical Research, vol. 36, no.5, pp. 575-581, 2002.

[25] M. D. Shah \& M. A. Hossain, "Total Flavonoids Content and Biochemical Screening of the Leaves of Tropical Endemic Medicinal Plant Merremia borneensis," Arabian Journal Chemistry, vol. 7, no. 6, pp. 1034-1038, 2014.

[26] V. E. Tyler, L. R. Brady, \& J. E. Robbers, Pharmacognosy, 9th ed. Philadelphia: Lea and Febiger, 1988.

[27] B. S. Nayak, S. S. Raju, F. A. Orette, \& A. V. C. Rao, "Effects of Hibiscus rosa sinensis L (Malvaceae) on Wound Healing Activity: A Preclinical Study in a Sprague Dawley Rat," The International Journal Lower Extremity Wounds, vol. 6, no. 2, pp. 76-8, 2007.

[28] J. Lachman, M. Orsak, A. Hejtmankova, \& E. Kovarova, "Evaluation of Antioxidant Activity and Total Phenolics of Selected Czech Honeys," Food Science and Technology, vol. 43, no.1, pp. 52-58, 2010.

[29] S. Gorinstein et al., "The Comparative Characteristics of Snake and Kiwi Fruits," Food and Chemical Toxicology, vol. 47, no. 8, pp. 1884-1891, 2009.

[30] M. I. B. Abdullah, "Physicochemical Profiling and Detection of Phenolic Constituents with Antioxidant and Antibacterial Activities of Myristica fragrans Houtt," thesis, University Sains Malaysia, Penang, 2009.

[31] V. Baltrusaityte, P. R. Venskutonis, \& V. Ceksteryte, "Radical Scavenging Activity of Different Floral Origin Honey and Beebread Phenolic Extracts," Food Chemistry, vol. 101, no.2, pp. 502-514, 2007.

[32] G. Saric et al., "Changes of Antioxidant Activity and Phenolic Content in Acacia and Multifloral Honey during Storage," Food Technology and Biotechnology, vol. 50, no. 4, pp. 434-441, 2012.

[33] I. A. A. da Silva et al., "Phenolic Profile, Antioxidant Activity and Palynological Analysis of Stingless Bee Honey From Amazonas, Northern Brazil," Food Chemistry, vol. 141, no. 4, pp. 3552-3558, 2013.

[34] L. Estenvinho, A. P. Pereira, L. Moreira, L. G. Dias, \& E. Pereira, "Antioxidant and Antimicrobial Effects of Phenolic Compounds Extracts of Northeast Portugal Honey," Food and Chemical Toxicology, vol. 87, no. 6, pp. 1069-1075, 2008. 